\title{
Effects of Xylitol and Glucose on Insulin Release from Dog Pancreas Tissue in vitro
}

\author{
Yoshimasa TASAKA, HISAKo NAKAMURA, \\ MAYOSHI SO AND KINORI KOSAKA \\ Department of Internal Medicine Tokyo Women's Medical College 10, \\ Ichigaya Kawadacho Shinjuku-ku, Tokyo
}

\begin{abstract}
Synopsis
In order to study the mechanism of insulin release by xylitol and glucose, in vitro experiments were done in dog pancreas tissue, using the method described by Malaisse $e$ t al. Xylitol and glucose in low concentration $(60 \mathrm{mg} / 100 \mathrm{~m} l)$ did not stimulate insulin release above base line values observed in the absence of sugar. High concentration of xylitol and glucose $(300 \mathrm{mg} / 100 \mathrm{~m} l)$ stimulated insulin release significantly, but the amount of insulin released by xylitol was not so much as that by the same concentration of glucose. The insulin-stimulatory effects of glucose and xylitol were inhibited by the addition of epinephrine or propranolol. 2,4-dinitrophenol blocked them, too. Mannoheptulose inhibited the release of insulin by glucose, but it had no significant effects on xylitol-induced insulin release. These results suggest that xylitol has a direct insulinstimulatory effect in dog pancreas tissue and that there may be a common path in the mechanism of insulin release by xylitol and glucose after it has been metabolized in pancreatic islets.
\end{abstract}

In vivo, xylitol stimulates insulin secretion in dogs (Hirata et al., 1966; Kuzuya et al., 1969a; Wilson and Martin, 1970), men (Kosaka, 1967; Maruhama et al., 1967; Spitz et al., 1969), monkeys (Wilson and Martin, 1970), rabbits and rats (Kuzuya et al., 1969b), and in vitro in rats (Montague and Taylor, 1968) and mice (Onoe et al., 1967). Kuzuya et al. (1969a) reported that the stimulating effect of the pentitol was most conspicious in dogs in vivo and weak in men or in rabbits. Therefore, in order to study the direct effect of xylitol on secretion of insulin, the use of dog pancreas tissue would be more suitable.

Xylitol is known to enter the pentosephosphate pathway via D-xylulose-5-phosphate (Touster, 1960). The present investigation was designed to study the effect of xylitol on insulin secretion and its mechanism of insulin release in canine pancreas tissue in

Received for publication July 5, 1971. vitro in comparison with that of glucose.

\section{Materials and Methods}

\section{Dogs}

Mongrel dogs weighning 7 to $10 \mathrm{~kg}$ were used. They were fed CD-I for dog food (Japan CLEA Co., Ltd.). Preliminary studies had indicated that fasting would diminish the responsiveness of the pancreas tissue to the stimulation of insulin release in vitro. Thus non-fasted dogs were used in these investigations except that on mannoheptulose. Dogs were anesthetized with nembutal administered iv (about $30 \mathrm{mg} / \mathrm{kg}$ ), and blood was removed as completely as possible through a cannulated carotid artery, and the pancreas was carefully dissected out. The visceral peritoneum covering the surface of the pancreas was stripped off and the left lobe of the pancreas was used for the experiment.

\section{Incubation of Pancreas Tissue}

The excised pancreas was cooled in oxygenated Krebs-Henseleit bicarbonate buffer (Krebs and Henseleit, 1932) rapidly freed of adipose tissue, blood 
clots and vessels, and was cut with a razor into small pieces of ca. $10 \mathrm{mg}$. The pancreas pieces (four pieces) were distributed as uniformly as possible in $2 \mathrm{ml}$ of bicarbonate medium containing $5 \mathrm{mg} / \mathrm{ml}$ of bovine albumin (Cohn Fraction V, Daiichi Pure Chemicals Co., Ltd., Tokyo, Japan), a sufficient amount of antipork insulin serum (Malaisse et al., 1967a) and a given amount of test substances, equilibrated with $\mathrm{O}_{2}+$ $\mathrm{CO}_{2}$ (95:5). The flasks were flushed with the gas mixture, stoppered and incubated in a water-bath at $37^{\circ} \mathrm{C}$ for 90 min with shaking at $90-100$ strokes/min. At the end of incubation, the flasks were cooled with iced water and the media were transferred to test tubes for further determination. Then the pancreas pieces were weighed.

\section{Measurement of Insulin Release}

The amount of released insulin in the incubation flasks was determined by the method described by Malaisse et al. (1967a), which combined the released insulin with enough guinea pig anti-insulin serum, thus protecting the destruction of insulin by pancreatic insulinase (Tasaka and Campbell, 1968). In our preliminary experiments, no lytic effect of pancreas tissue was found according to this method. In each experiment, crystalline dog insulin (20 I.U./mg, by courtesy of Dr. Y. Koga of Shimizu-Seiyaku Co., Ltd.) was used as the standard and the dextran-coated charcoal was used for the separation of bound insulin from free insulin (Herbert et al., 1965). Pork insulin labelled with ${ }^{131}$ I was obtained commercially (Dainabot radioisotope laboratory, Tokyo, Japan).

Thirty min after the end of incubation, $0.5 \mathrm{ml}$ of sample, in duplicate, was taken and added to a test tube with $0.35 \mathrm{ml}$ of bicarbonate medium containing

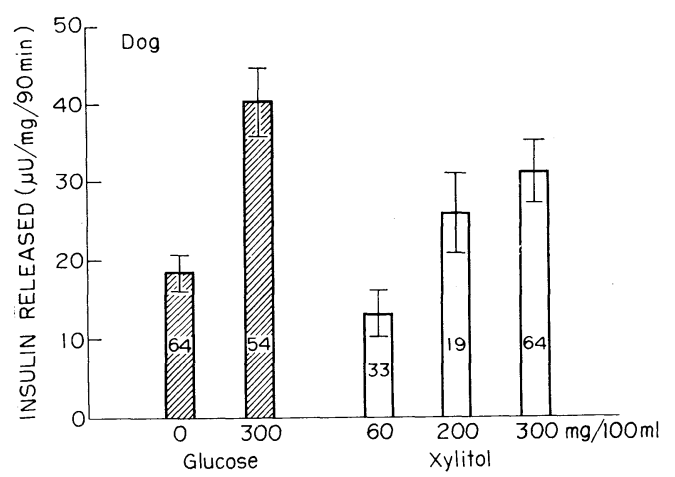

Fig. 1. Stimulation of insulin release by glucose and xylitol. The numbers with the bars represent the number of flasks containing pancreas tissue which were used for each experiment. The standard error of the mean is shown by the vertical line at the top of each bar. labelled and unlabelled insulin, $1000 \mathrm{~K}$ I.U. of Trasylol (Bayer Leverkusen) and $5 \mathrm{mg} / \mathrm{m} l$ of bovine albumin for back titration of insulin (Malaisse et al., 1967a), Trasylol was added for the protection of added insulin from insulinase. Total released insulin was divided according to the weight of pancreas tissue. In each experiment the value of released insulin before starting incubation was subtracted.

\section{Chemicals}

Xylitol was generously supplied by Eisai Co., Ltd., Tokyo. Epinephrine was obtained from Daiichi Seiyaku Co., Ltd., Tokyo, propranolol from Sumitomo Chemical Co., Ltd., Osaka, D-glucose from Kanto Chemical Co., Ltd., Tokyo, and mannoheptulose was from Planstiehl Laboratories Inc., Ill.

\section{Results}

\section{Effects of xylitol and glucose concentration}

The release of insulin from dog pancreas tissue in vitro was measured at the concentrations of 0 and $300 \mathrm{mg} / 100 \mathrm{~m} l$ glucose, and of 60,200 and $300 \mathrm{mg} / 100 \mathrm{~m} l$ xylitol (Fig. 1). The amount of released insulin at sugar free medium was $18.8 \pm 2.5 \mu \mathrm{U} / \mathrm{mg} / 90$ min (Mean $\pm \mathrm{SE})$ and it increased up to $40.1 \pm 4.6$ $\mu \mathrm{U} / \mathrm{mg} / 90 \mathrm{~min}$ at $300 \mathrm{mg} / 100 \mathrm{~m} l$ glucose $(p<0.01)$. Xylitol stimulated insulin release, too. The amount of released insulin at 60 $\mathrm{mg} / 100 \mathrm{~m} l$ Xylitol was $13.7 \pm 3.2 \mu \mathrm{U} / \mathrm{mg} / 90$ $\min ($ Mean $\pm \mathrm{SE}$ ). At 200 and $300 \mathrm{mg} / 100 \mathrm{~m} l$ xylitol, the values of released insulin were $26.0 \pm 5.3 \mu \mathrm{U} / \mathrm{mg} / 90 \mathrm{~min}$ and $31.2 \pm 4.4$ $\mu \mathrm{U} / \mathrm{mg} / 90 \mathrm{~min}$, respectively. The latter was significantly higher than that in sugar free medium $(\mathrm{p}<0.05)$. At their high concentration $(300 \mathrm{mg} / 100 \mathrm{ml})$, the value of insulin released in xylitol medium had a tendency to be lower than that in glucose $(0.1<\mathrm{p}<0.5)$.

\section{Effects of epinephrine and propranolol}

Effects of adrenergic agents on release of insulin were investigated. Epinephrine $(2 \mu M)$ inhibited significantly $(p<0.01)$ release of insulin by high concentration of glucose or xylitol (Table 1). The mean values of insulin in glucose medium decreased from $59.2 \pm$ 
Table 1. Effects of epinephrine and propranolol on insulin release

\begin{tabular}{|c|c|c|}
\hline Medium & $\begin{array}{l}\text { Concn of } \\
\text { inhibitors }\end{array}$ & $\begin{array}{l}\text { Insulin release } \\
(\mu \mathrm{U} / \mathrm{mg} / 90 \mathrm{~min})\end{array}$ \\
\hline Glucose $(0 \mathrm{mg} / 100 \mathrm{~m} l)$ & & $21.0 \pm 3.5(24)$ \\
\hline Glucose $(300 \mathrm{mg} / 100 \mathrm{ml})$ & & $59.2 \pm 8.4(18)$ \\
\hline Glucose ditto & Epinephrine $(2 \mu \mathrm{M})$ & $31.7 \pm 3.7(22)$ \\
\hline Glucose & Propranolol $(300 \mu \mathrm{M})$ & $25.8 \pm 6.0(22)$ \\
\hline Xylitol $(300 \mathrm{mg} / 100 \mathrm{~m} l)$ & & $50.8 \pm 7.9(24)$ \\
\hline Xylitol ditto & Epinephrine $(2 \mu \mathrm{M})$ & $25.2 \pm 4.9(24)$ \\
\hline Xylitol & Epinephrine $(0.4 \mu \mathrm{M})$ & $40.9 \pm 7.9(20)$ \\
\hline Xylitol & Propranolol $(300 \mu \mathrm{M})$ & $17.8 \pm 3.5(24)$ \\
\hline Xylitol & Propranolol ( $60 \mu \mathrm{M})$ & $51.6 \pm 7.3(24)$ \\
\hline
\end{tabular}

The experimental conditions are described in Materials and Methods. The results are given as the means $\pm \mathrm{SE}$ and the numbers of observations are given in parentheses.

Table 2. Inhibition of insulin release by 2,4-dinitrophenol

\begin{tabular}{lcc}
\hline \multicolumn{1}{c}{ Medium } & $\begin{array}{c}\text { Concn of DNP } \\
(\mathrm{mM})\end{array}$ & $\begin{array}{l}\text { Insulin release } \\
(\mu \mathrm{U} / \mathrm{mg} / 90 \mathrm{~min})\end{array}$ \\
\hline Glucose $(0 \mathrm{mg} / 100 \mathrm{~m} l)$ & & $20.9 \pm 4.8(16)$ \\
Glucose $(300 \mathrm{mg} / 100 \mathrm{~m} l)$ & & $68.0 \pm 11.5(12)$ \\
Glucose $(300 \mathrm{mg} / 100 \mathrm{~m} l)$ & 0.3 & $28.2 \pm 9.9(11)$ \\
Xylitol $(300 \mathrm{mg} / 100 \mathrm{~m} l)$ & & $53.7 \pm 11.4(16)$ \\
Xylitol $(300 \mathrm{mg} / 100 \mathrm{~m} l)$ & 0.3 & $23.0 \pm 8.4(13)$ \\
\hline
\end{tabular}

The results are given as the means $\pm \mathrm{SE}$ and the numbers of observations are given in parentheses.

$8.4 \mu \mathrm{U} / \mathrm{mg} / 90 \mathrm{~min}$ to $31.7 \pm 3.7 \mu \mathrm{U} / \mathrm{mg} / 90$ min and in xylitol medium from $50.8 \pm 7.9$ $\mu \mathrm{U} / \mathrm{mg} / 90 \mathrm{~min}$ to $25.2 \pm 4.9 \mu \mathrm{U} / \mathrm{mg} / 90 \mathrm{~min}$, close to base line value of $21.0 \pm 3.5 \mu \mathrm{U} / \mathrm{mg} /$ $90 \mathrm{~min}$ in the absence of sugar. Lower concentration of epinephrine $(0.4 \mu M)$ inhibited release of insulin by xylitol to a lesser degree. Propranolol $(300 \mu M)$ also inhibited release of insulin by both sugars $(\mathrm{p}<0.01)$, but 60 $\mu M$ of propranolol had no inhibition of insulin release by xylitol.

\section{Effects of 2,4-dinitrophenol and manno- heptulose}

2,4-dinitrophenol $(0.3 \mathrm{mM})$ was added to the incubation medium containing glucose $(300 \mathrm{mg} / 100 \mathrm{~m} l)$ or xylitol $(300 \mathrm{mg} / 100 \mathrm{~m} l)$ (Table 2). The release of insulin by each sugar was inhibited significantly $(p<0.01)$ in the presence of $0.3 \mathrm{mM}$ dinitrophenol. Man- noheptulose $(200 \mathrm{mg} / 100 \mathrm{ml})$ blocked insulin release by glucose $(\mathrm{p}<0.05)$, but it had no inhibitory effect on xylitol-induced insulin release $(p>0.5)$ (Table 3$)$.

\section{Discussion}

The present investigation demonstrated that both glucose and xylitol stimulated insulin release from dog pancreas tissue in vitro by a direct effect on the islets of Langerhans as well as in vivo (Kuzuya and Kanazawa, 1969). Similar results were reported in rat pancreatic islets (Montague and Taylor, 1968). The amount of insulin released by xylitol did not differ significantly from the control values at low concentrations of xylitol, but at a high concentration $(300 \mathrm{mg} / 100 \mathrm{ml})$ it increased as much as with glucose. 
Table 3. Effects of mannoheptulose on insulin release

\begin{tabular}{ccc}
\hline \hline $\begin{array}{c}\text { Medium } \\
(300 \mathrm{mg} / 100 \mathrm{~m} l)\end{array}$ & $\begin{array}{c}\text { Concn of } \\
\text { mannoheptulose }(\mathrm{mg} / 100 \mathrm{~m} l)\end{array}$ & $\begin{array}{l}\text { Insulin release } \\
(\mu \mathrm{U} / \mathrm{mg} / 90 \mathrm{~min})\end{array}$ \\
\hline Glucose & & $36.1 \pm 6.2(18)$ \\
Glucose & 200 & $15.7 \pm 4.0(18)$ \\
Xylitol & & $26.9 \pm 5.0(24)$ \\
Xylitol & 200 & $23.7 \pm 4.6(22)$ \\
\hline
\end{tabular}

The results are given as the means $\pm \mathrm{SE}$, and the numbers of observations are given in parentheses.

Dogs were fasted for $18 \mathrm{hr}$.

The stimulus of xylitol to insulin secretion in dog pancreas in vivo was reported to be more potent than that of glucose (Kuzuya et al., 1969a), but in these in vitro experiments such a result could not be obtained. In general, glucose tended to exert a stronger effect on insulin release than xylitol. The reason for this difference in insulin release is not clear. One explanation may be that, in in vivo experiments, xylitol is rapidly metabolized in pancreatic islets and intermediate substance stimulates insulin secretion as it is metabolized in liver (Krebs et al., 1966) and adipose tissue (Mori et al., 1967), although the results of Montague and Taylor (1968) disagree. Another possibility is that the high concentrations of glucose stimulate the biosynthesis of insulin (Howell and Taylor, 1967; Lin and Haist, 1969) and proinsulin and newly synthethized insulin appear in the medium after $60 \mathrm{~min}$ of incubation (Steiner, 1967), while xylitol may not have this effect (Lin and Haist, 1969).

Epinephrine, a potent activator of the $\alpha$-adrenergic receptor (Ahlquist, 1948), inhibited insulin release by xylitol as well as by glucose, and propranolol, a $\beta$-adrenergic inhibitor, blocked, too. These results suggest that xylitol has a common insulin secretory mechanism with glucose connected with $\alpha$-and $\beta$-adrenergic receptor system.

Mannoheptulose suppressed insulin release by glucose in dog pancreas tissue in vitro, but it did not affect the insulin release by xylitol. The amount of released insulin in the presence of glucose was lower than that in other experi- ments. One reason may be that this experiment was done to the fasting dog, since the effect of mannoheptulose was more potent on the pancreas tissue from the fasted animal (Malaisse et al., 1967b). Mannoheptulose is a known hexokinase inhibitor (Ashcroft and Randle, 1968; Malaisse et al., 1968), and xylitol is metabolized through xylulose to pentose phosphate pathway. Therefore it is conceivable that the insulin release by xylitol is not affected by mannoheptulose. On the other hand, the effects of xylitol and glucose are likely to be dependent on anaerobic ATPgenerating system as indicated by the inhibitory effects of 2,4-dinitrophenol. The pentose phosphate pathway is known to play a role in the secretion of insulin in response to glucose and high activity of the enzymes of this pathway has been demonstrated in pancreatic islets (Field et al., 1960; Kissane et al., 1964). Whether the stimulation of insulin secretion by glucose or xylitol is imedated through enzymatic activation or some intermediate metabolites in this pathway remains to be elucidated.

\section{Acknowledgements}

We thank Dr. A Kaneto, Tokyo Women's Medical College, for his valuabl advice and criticism and Miss K. Murakami for her skilful assistance.

\section{References}

Ahlquist, R. P. (1948). Am. J. Physiol. 153, 
586.

Ashcroft, S. J. H. and P. J. Randle (1968). Biochem. J. 107, 599.

Field, J. B., P. Johnson, B. Herring and A. N. Weinberg (1960). Nature (London) 185, 468.

Herbert, V., K. S. Lan, C. Gottlieb and S. J. Bleicher (1965). J. Clin. Endocrinol. 25, 1375.

Hirata, Y., M. Fujisawa, H. Sato, T. Asano and S. Katsuki (1966). Biochem. Biophys. Res. Commun. 24, 471.

Howell, S. L. and K. W. Taylor (1967). Biochem. J. 102, 922.

Kissane, J. M., P. E. Lacy, S. E. Brolin and C. H. Smith. The Structure and Metabolism of the Pancreatic Islets (edited by S. E. Brolin et al.). Pergamon Press Ltd., Oxford P 281 (1964).

Kosaka, K. International Symposium on Metabolism, Physiology, and Chemical Use of Pentoses and Pentitols, Hakone, Japan P 243 (1967).

Krebs, H. A. and K. Henseleit (1932). Z. Physiol. Chem. 210, 33.

Krebs, H. A., B. M. Notton and R. Hems (1966). Biochem. J. 101, 607.

Kuzuya, T., Y. Kanazawa and K. Kosaka (1969a). Endocrinology 84, 200.

Kuzuya, T., Y. Kanazawa and M. Hayashi (1969b). J. Japan Diabetic Society 12, 48.

Kuzuya, T. and Y. Kanazawa (1969). Diabetologia 5, 248.
Lin, B. J. and R. E. Haist (1969). Can. J. Physiol. Pharmacol. 47, 791.

Malaisse, W. J., F. Malaisse-Lagae and P. H. Wright (1967a). Endocrinology 80, 99.

Malaisse, W. J., F. Malaisse-Lagae and D. Mayhew (1967b). J. Clin. Invest. 46, 1724.

Malaisse, W. J., M. A. Lea and F. MalaisseLagae (1968). Metabolism 17, 126.

Maruhama, Y., M. Anzai, A. Ohneda, Y. Goto and S. Yamagata (1967). Abst. 6th Congr. int. Diabetes Fed; Excerpta med. 140, 44.

Montague, W. and K. W. Taylor (1968). Biochem. J. 109, 333.

Mori, K., T. Kanatsuna and K. Kuzuya (1967). Abstr. 6th. Congr. int. Diabetes Fed; Excerpta med. 140, 161.

Onoe, K., K. Kobashi, T. Yamamoto, S. Fujinaka and T. Aburaya (1967). Folia endocrinol. Japon. 43, 277. (In Japanese). Spitz, I. M., A. H. Rubenstein, I. Bersohn and K. H. Bässler (1969). Metabolism 18, 24.

Steiner, D. F. (1967). Tr. New York Acad. Sci. II 30, 60.

Tasaka, Y. and J. Campbell (1968). Can. J. Biochem. 46, 483.

Touster, O. (1960). Fed. Proc. 19, 977.

Wilson, R. B. and J. M. Martin (1970). Diabetes 19, 17. 